無分離迄り腰椎の $\mathrm{X}$ 線学的検討

一㞄動吇心と椎間関節の変化について—

烏取大学医学部整形外科

崳長 靖 生・前山上璇
川 俊 文

\title{
Radiological Examination of Pseudospondylolisthesis \\ - on Instant Center and Change of Facet Joint-
}

by

\section{Yasuo Sakinaga, Iwao Maeyama and Toshifumi Kawakami Department of Orthopedic Surgery, Tottori University \\ School of Medicine}

\begin{abstract}
Instant centers of 51 patients of pseudospondylolisthesis, 58 patients of lumbar instability and 55 patients of lumbago were compared. In pseudospondylolishesis, instant centers were placed lower than these of other two groups and the vertebral motion was considered rotatinal movement.

Degenerative changes of fecet joint and anterior inclinations of articular processes were related to the low position of instant center. Posterior portinos of motion segment were more important than the disc degeneration as a factor of the vertebral slip in pseudospondylishtesis.
\end{abstract}

腰倠の前後屈運動における椎体の移動を回転運動と してとらえ，腰痛症患者についてはその運動中心 （instant center）を計测し，既に第60 回中部日本 整形外科災害外科学会で報告した. 今回, 無分離えり 症患者及び之りのない不安定症患者につき運動中心を 計測し, 腰痛症患者之の比較を行った. 又, 種々のX 線学的計測を行ない，運動中心の観点から椎体運動之 の関連についても検討した.

\section{対象}

第 4 腰椎無離过り症患者 51 名 (男 13 名, 女 38 名), 年令 38 才 81 才（平均 56.8 才）及び不安定症患者 58 名（男 17 名，女 41 名），年令 13 才 65 才（平均 41.2才）を対象とした.

\section{調 查 事 項}

(1)亖り率（コンパステストにより迄り度/过り椎前 後径 $\times 100$ ) (2) 運動中心（最大前屈, 最大後屆㑡面X
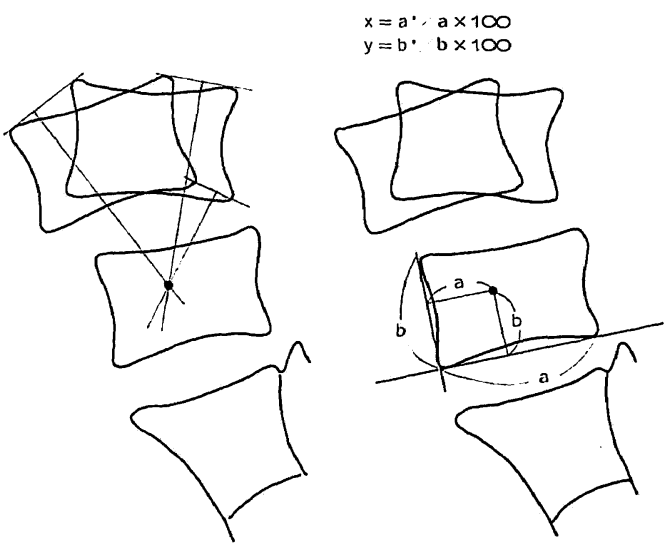

図 1 運勘中心の求方 最大前屈・後屈例面X線写真を重ね合わ せ運動中心を決定する，その位置をX， Y座標として表わす。

線写真より図 1 の方法) (3)椎弓角・上関節突起角（村 上. ${ }^{3}$ の方法) (4)椎間関節の変化（串田の関節裂隙の分 


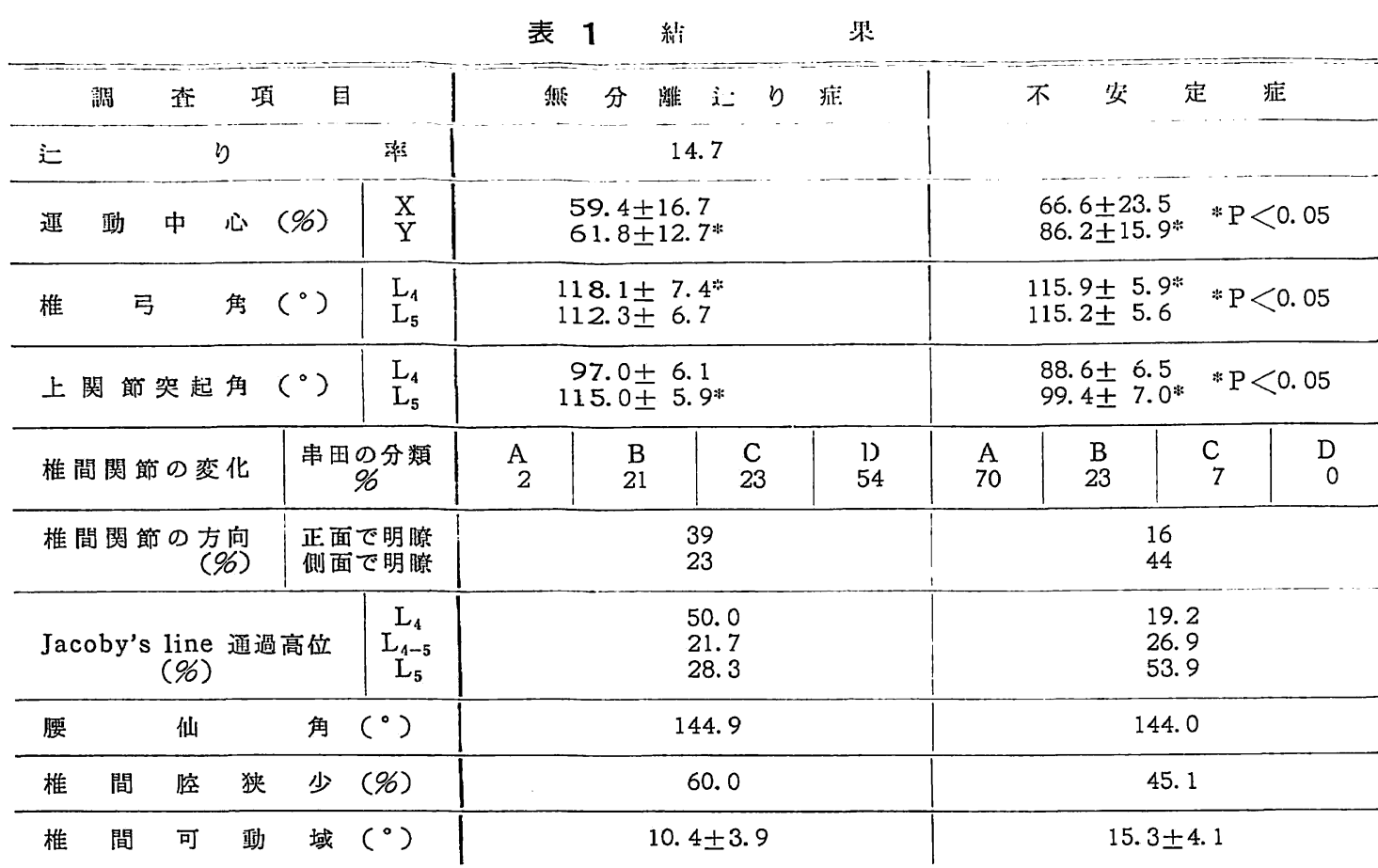

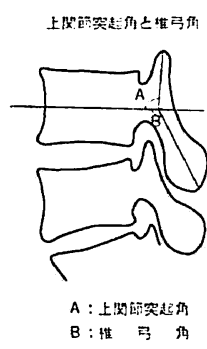

(A)

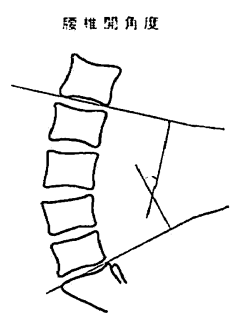

(B)
保们

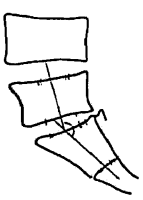

(C)
ない. 前屈位で 5 \%以上の迄り増加は $65.9 \%$ みら れた.

（2）運動中心：両群とあにX值は $60 \%$ 前後で 差 はない.Y值は無分離逐り症で約 $20 \%$ 低值であった. 無分離过り症での運動中心は頭尾方向には $\mathrm{L}_{5}$ 椎体中 央付近にあり, 不安定症では $\mathrm{L}_{5}$ 椎体上縁付近にあ る.

（3）椎間可動域：不安定症の方が約 1.5 倍の可動 域がある.

（4）椎弓角： $\mathrm{L}_{5}$ では両群に差はない. $\mathrm{L}_{4}$ では無 分離过り症の方が約 $6^{\circ}$ 大きく, 椎弓 ・下関節哭起は 前傾化している.

（5）上関節突起角： $\mathrm{L}_{4}$ では両群に差はない. $\mathrm{L}_{5}$ では無分離二り症の方が約 $11^{\circ}$ 小さく, 上関節突起す 前傾している.

（6）椎間関節の変化：無分離之り症では半数以上 が Dに分類され，Cとを合わさると77\%に明らかな 変化がみられた． 不安定症ではAが $70 \%$ 占め，明 らかな変化のある C は $7 \%$ しなくて，Dは 1 例むな かった.

（7）椎間関節の方向性：正面X線像で関節裂隙が 明暸となる, 所謂矢状面のものは热分離过り症で多 
く，側面 X線像で明嶛となる，所謂前額面のものは不 安定症に多い.しかし両群とむに関節面の方面は所拥 斜位面のものが坟も多かった。

（8）Jacoby 線の高さは，热分離之り症では $\mathrm{L}_{4}$ 椎 体を通過する例が多く，不安定症では $\mathrm{L}_{5}$ 椎体を通過 する例が多い。

（9）腰仙角は両群で差はない，腰椎開角度にも統 計上の有意差は認めなかった。

（10）椎間空狭小の有然：不安定症では 40 才以： 31 名を対象とした。雨群にも統計上の有意差はみと められなかった。

\section{考察}

既に報告した腰痛症患者の第 4 腰椎の運動中心（表 2）と無分離之り症及び不安定症での運動中心を比較 すると, 不安定症では前後方向・頭尾方向とあに余り 差はない． 無分離之り症では 前後方向には差はない が，頭尾方向では明らかに近い位置にある.又，椎間可 動域は腰痛症患者と無分離过り症患者では差は余りな いが, 不安定症患者では大きくなっている.以上てのて とから，不安定症では，腰痛症の場合とほぼ同じ点を 中心としての回転運動をしているが，運動䉪囲が增大 しているために前屈時に椎間腔の前縁つぶれ後縁開大 が起てるすのと推测される. 一方, 無分離之り症で は，より低い位置を中心としての回転運動をするため に水平方向の運動成分の增大により汒がみられるも のと考えられる.

このような無分離之り症の運動中心の下方移動之椎 弓・椎間関節などの後方要素の変化の関連について考 えてみる. まず椎弓角は不安定症では $\mathrm{L}_{4}$ よりも $\mathrm{L}_{5}$ の 方が増大し，腰痛症でも同様の傾向であったが，無分 離过り症では逆に $\mathrm{L}_{4}$ 椎弓角の方が増大, 即ち前傾化 していた. 上関節突起角は迄り下位椎で減少, 即ち前 傾向がみられ, 椎弓角の変化之対応しているあの之思 わ机る. 従って前後屈運動において, 过り椎下関節突 起は下位椎上関節突起を乗り越える2)というよりは， 低い位置にある運動中心の回りを回忶運動し、これに 対応した惟間関節は適合性を保っているあのと考えら れる。

さらに椎間関節の変形性変化む無分離之り症の特 徽4) とされ, 私達の今回の結果からむ, 正りと何らか の関連をむつものと云える. 少数例ながら, 皿分離过 り症及び腰痛症での椎間関節の変化の怪度な例（串出
表 2

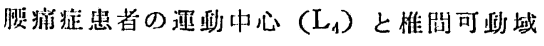

\begin{tabular}{|c|c|c|c|}
\hline & $\mathrm{X}(\%)$ & Y (\%) & $\mid \begin{array}{c}\mid \text { 可䣦域 } \\
\left({ }^{\circ}\right)\end{array}$ \\
\hline $\begin{array}{l}40 \text { f 代 }(\mathrm{n}=20) \\
50 \text { 代 }(\mathrm{n}=21) \\
60 \text { 代 }(\mathrm{n}=14)\end{array}$ & $\begin{array}{l}61.5( \pm 13.1) \\
62.2( \pm 14.9) \\
691( \pm 29.7)\end{array}$ & $\begin{array}{l}95.6( \pm 20.9) \\
91.6( \pm 25.9) \\
90.6( \pm 20.5)\end{array}$ & $\begin{array}{r}11.5 \\
11.5 \\
9.8\end{array}$ \\
\hline
\end{tabular}

椎䦌刹節の变化と迺䣦中心

槚捔证患者

\begin{tabular}{c|c|c}
\hline 阅節の変化 & 症例 数 & $Y$ 值 の平均 \\
\hline $\mathrm{A}$ 及び B & 15 & $100.1( \pm 22.4)$ \\
$\mathrm{C}$ & 5 & $65.0( \pm 15.6)$
\end{tabular}

無分離汇り症患者

\begin{tabular}{c|c|c}
\hline 网節の変化 & 症 例 & $\mathrm{Y}$ 做 \\
\hline $\mathrm{A}$ 及び $\mathrm{B}$ & 8 & $76.5 \pm 35.2$ \\
$\mathrm{C}$ 及びD & 32 & $66.1 \pm 22.8$
\end{tabular}

の分類 A, B ) と高度な例（分類 C, D) とについて 運動中心を比校すると頭尼方向の位羁 $Y$ の平均值は高 度例では低下する傾向がうかがわれる、関節の変形は 運動中心の下方移動を引きおこす可能性も考えられ る. しかし椎間腔狄少化の頻度は不安定症との間に有 意差をみとめなかった事より，無分離之り症の局所的 変化としては後方要絭の変化が重要であると考えてい る.

えりの全身的力学的要因としての腰仙角や掼椎開任 度には今回の結果では不安定症と差がなく、Jacoby 線通過高位では差をみとめた. 從来から春柱彎状態5) との関連や大腿骨頭の位置との関連などについて報告 されているが，てれら金身的要因の動的状態の把握 む 今後榆討されねばならない。

\section{文献}

1）串田俊郎：椎間関節を中心とする媵椎通怔のレ 線学的研究. 中部整災誌, 6: 952-994, 1963.

2) MacNab, I.: Spondylolisthesis with an intact neural arch. J. Bone Joint Surg., 32-B: 325-333, 1950.

3）村上弓夫・伤逸志 - 他：Degnerative spondylolisthesis について. 整北外科, 24:819826, 1973.

4) 角田信昭 - 黒瀬真之助 - 他：Degenerative spondylolisthesis $の \mathrm{X}$ 線学的検討. 臨整外, 15: 851-859, 1980.

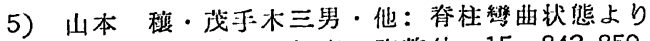
みた然分離脊椎すべり症. 臨整外, 15:842-850, 1980. 